\title{
Light sources and culture media in the in vitro growth of the Brazilian orchid Microlaelia lundii
}

\section{Fontes de luz e meios de cultura no crescimento in vitro da orquídea brasileira Microlaelia lundii}

\author{
Vanessa Favetta ${ }^{1 *}$; Ronan Carlos Colombo ${ }^{2}$; \\ José Fernando Mangili Júnior ${ }^{3}$; Ricardo Tadeu de Faria ${ }^{4}$
}

\begin{abstract}
The Brazilian micro-orchid Microlaelia lundii enchants by its beautiful blooms in winter, but its cultivation is still a challenge, requiring specific care. The objective of this work was to evaluate the influence of light sources and culture media on in vitro growth and ex vitro survival of this micro-orchid. M. lundii seedlings were transferred to flasks containing the culture medium $1 / 2$ MS and Simplified Medium, consisting of $5 \mathrm{~mL} \mathrm{~L}^{-1}$ of Biofert Plus ${ }^{\circledR}$ NPK fertilizer (09-08-09) and $60 \mathrm{~g} \mathrm{~L}^{-1}$ of 'Nanica' banana pulp. These flasks were placed in a growth chamber composed of seven environments, characterized by types of lighting: L1) LEDtube 4000K; L2) LEDtube 6500K; L3) L1 + L2; L4) L1 + L1; L5) red LED; L6) blue LED; L7) fluorescent lamp (control). After 200 days of cultivation, biometric growth parameters and leaves chlorophyll content were evaluated together with the percentage of seedling survival when acclimatized. At the end of the experiment, an analysis of individual variances and a combined analysis of the environments were carried out. The simplified medium led to higher seedlings, especially for light source L6. Light sources L1, L2, L3 and L4 promoted an increase in the seedlings root system in the simplified medium. As for the chlorophyll content, L4 and L7 showed higher contents of chlorophyll $a$ and $b$. The simplified medium led practically to $100 \%$ of seedling survival, regardless of the light source used. Results shown that the simplified medium under light sources L1, L2, L3 and L4 is recommended for the in vitro propagation of $M$. lundii.
\end{abstract}

Key words: LED. Nutritious medium. Orchidaceae. Quality of light.

\section{Resumo}

A micro-orquídea brasileira Microlaelia lundii encanta pelas belas floradas no inverno, no entanto o seu cultivo ainda é um desafio, requerendo cuidados específicos. Assim, objetivou-se avaliar a influência de fontes de luz e meios de cultura no crescimento in vitro e na sobrevivência ex vitro dessa microorquídea. Plântulas de $M$. lundii foram transferidas para frascos contendo os meios de cultura: $1 / 2 \mathrm{MS}$ e Meio Simplificado, composto por $5 \mathrm{~mL} \mathrm{~L}^{-1}$ do fertilizante Biofert Plus ${ }^{\circledR}$ NPK (08-09-09) e $60 \mathrm{~g} \mathrm{~L}^{-1}$ de polpa de banana 'Nanica'. Estes frascos foram acondicionados em câmara de cultivo composta por sete ambientes, caracterizados pelo tipo de iluminação: L1) LEDtube 4000K; L2) LEDtube 6500K; L3) L1 + L2; L4) L1 + L1; L5) LED vermelho; L6) LED azul; L7) Lâmpada fluorescente (controle). Após 200 dias de cultivo, avaliou-se o crescimento da parte aérea e do sistema radicular das plantas e

\footnotetext{
${ }^{1}$ M.e em Agronomia, Departamento de Agronomia, Universidade Estadual de Londrina, UEL, Londrina, PR, Brasil. E-mail: vanfavetta@hotmail.com

2 Discente, Curso de Doutorado do Programa de Pós-Graduação em Agronomia, UEL, Londrina, PR, Brasil. E-mail: ronancolombo@ yahoo.com.br

3 Prof. Dr., Departamento de Engenharia Elétrica, UEL, Londrina, PR, Brasil. E-mail: mangili@uel.br

${ }^{4}$ Prof. Dr., Departamento de Agronomia, UEL, Londrina, PR, Brasil. E-mail: faria@uel.br

* Author for correspondence
} 
o teor de clorofila nas folhas. Também, avaliou-se a porcentagem de sobrevivência das plantas, quando aclimatizadas. O meio simplificado propiciou plântulas mais altas, com destaque para a fonte de luz L6. As fontes de luz L1, L2, L3 e L4 no meio simplificado proporcionaram aumento do sistema radicular das plântulas. Quanto ao teor de clorofila, L4 e L7 apresentaram maiores teores de clorofila $a$ e $b$. O meio simplificado propiciou, praticamente, $100 \%$ de sobrevivência das plantas, independente da fonte de luz utilizada. Conclui-se que o meio simplificado nas fontes de luz L1, L2, L3 e L4 é recomendado para a propagação in vitro de $M$. lundii.

Palavras-chave: LED. Meio nutritivo. Orchidaceae. Qualidade da luz.

\section{Introduction}

Orchids are among the most cultivated ornamental plants in the world due to their economic potential and beautiful flowers. With prominence in this market, micro-orchids have attracted the interest of some growers and gaining space among flower consumers.

The Brazilian species Microlaelia lundii [(Rchb. f. \& Warm.) Chiron \& V. P. Castro] blooms beautifully in the winter and its small flowers, $3 \mathrm{x}$ $3 \mathrm{~cm}$ (WATANABE et al., 2002), are similar to the flowers of the Laelia purpurata species, drawing people's attention to their cultivation. However, the in vitro propagation and cultivation of this micro-orchid are not common, since this is not a domesticated species. Therefore, it is essential to adjust conditions for the in vitro propagation of the species, starting by the culture medium and growth chamber lighting.

Culture medium formulation must concentrate on essential substances for seedlings growth and development (STANCATO et al., 2009), according to each species needs (KERBAUY; CHAER, 2011; MIYATA et al., 2014). In the in vitro propagation of orchids, the modified MS medium (MURASHIGE; SKOOG, 1962) has been used by most plants biofactories (FARIA et al., 2002; MORAES et al., 2005), as well as several simplified media based on commercial fertilizers and organic components such as banana pulp, tomato pulp and coconut water (ARAÚJO et al., 2006; STANCATO et al., 2008; BAQUE et al., 2011; COLOMBO et al., 2012; SU et al., 2012; SOUZA et al., 2013; FAVETTA et al., 2014).
Besides the adaptation of the culture medium to the species, growth chamber lighting conditions must be adjusted since light quantity and quality provided to the propagating material are important to regulate the biochemical pathways that control growth and vegetal morphogenesis (LEE et al., 2007; TAIZ; ZEIGER, 2013). Although currently fluorescent lights are the most used (POUDEL et al., 2008), studies have been carried out to investigate the quality of the light emitted by LEDs (Light Emitting Diode) in promoting growth and morphogenesis in seedlings propagated in vitro (HEO et al., 2006; MENGXI et al., 2011; ROCHA et al., 2010). In addition, they found signs that the quality of light may affect the plants acclimatization process (NHUT et al., 2005).

Moreover, from the economical standpoint LEDs are more efficient, energy consumption is five times lower than that of $15 \mathrm{~W}$ fluorescent lamps, and, as the heat emitted by the LED lamp is also lower, it will do reduce the need for climatizing the environment (VALENTIM et al., 2010). Another economical advantage brought by LED lamps is related to maintenance since the durability of this light source is around seven times greater that of a common fluorescent light (GUPTA; JATOTHU, 2013). In addition, by being mercury-free, they become important for environment protection (VALENTIM et al., 2010).

Thus, the objective of this work was to evaluate the influence of light sources and culture media in the in vitro growth of the Brazilian orchid Microlaelia lundii. 


\section{Material and Methods}

This work was carried out at the Londrina State University Tissue Culture Laboratory, where assays were installed to compare the two culture media in seven environments characterized by lighting types.

Microlaelia lundii seedlings originated from seeds germinated in vitro in a MS culture medium with half of the macronutrients concentration ( $1 / 2$ MS) (MURASHIGE; SKOOG, 1962),180 days after seeding, with an average length of $5 \mathrm{~mm}( \pm$ 1) and from two to three shoots were transferred to culture media. These media contained: 1) 1/2 MS and 2) simplified medium with $5 \mathrm{~mL} \mathrm{~L}^{-1}$ of Biofert Plus ${ }^{\circledR}$ NPK (08-09-09) fertilizer and 'Nanica' banana pulp,
$60 \mathrm{~g} \mathrm{~L}^{-1}$, at the fourth maturation stage. Medium basis was composed of $30 \mathrm{~g} \mathrm{~L}^{-1}$ of sucrose, $1 \mathrm{~g} \mathrm{~L}^{-1}$ of activated charcoal and $8 \mathrm{~g} \mathrm{~L}^{-1}$ of agar; $\mathrm{pH}$ was adjusted to $6.0 \pm 0.2$ before the addition of the agar. Culture media were placed in $350 \mathrm{~mL}$ glass flasks with $50 \mathrm{~mL}$ of the medium and autoclaved at $121{ }^{\circ} \mathrm{C}$ and pressure of $1 \mathrm{~atm}$ for 25 minutes.

After transferring the seedlings to the culture media in a laminar flow chamber, flasks were kept in cultivation chambers with seven environments (Table 1). Each environment consisted of a MDF shelf $(123 \mathrm{~cm}$ of length; $50 \mathrm{~cm}$ of height; $66 \mathrm{~cm}$ of depth) isolated by styrofoam plates to prevent interference among the wavelengths emitted by the light sources.

Table 1. Characterization of light sources used for lighting Microlaelia lundii seedlings grown in vitro.

\begin{tabular}{llc}
\hline & \multicolumn{1}{c}{ Light source } & Illuminance (lux) \\
\hline L1 & LEDtube 4000k Philips cool white lamp & 1,840 \\
L2 & LEDtube 6500k Philips daylight lamp & 2,782 \\
L3 & L1 + L2 & 3,940 \\
L4 & L1 + L1 & 3,750 \\
L5 & Two strips of red LED & 112 \\
L6 & Two strips of blue LED & 157 \\
L7 & Fluorescent tube lamp OSRAM 40 W Special day light - control & 1,683 \\
\hline
\end{tabular}

Combination between culture medium and source of light consisted of a treatment composed of eight replications (flasks) with seven seedlings per flask, distributed randomly inside each environment.

Illuminance differences between lamps were measured by a luximeter (Table 1). The device was positioned at the flasks height in three different position in the shelf; central region, extremities and under the lighted area. Chamber temperature was kept at $25^{\circ} \mathrm{C} \pm 2$ at a photoperiod of 16 hours.

The analysis of LEDs and fluorescent lamp to characterize light quality was carried out at UEL Optics and Optoelectronics Laboratory and, from the data collected, a graph was generated in the MATLAB software.
At 200 days, the following biometric variables were evaluated: canopy height $(\mathrm{cm})$, number of shoots, canopy fresh and dry mass $(\mathrm{g})$, number of roots, roots average length $(\mathrm{cm})$, rots fresh and dry mass (g) and leaves chlorophyll content. Four flasks and 28 plants per treatment were evaluated.

To determine chlorophyll content, $50 \mathrm{mg}$ of foliar tissue was removed from the second and third leaf expanded from each replication to be macerated in acetone $80 \%$. After the maceration, samples were placed in graded tubes involved in aluminum foil (to protect the solution from the light) completing the volume to $10 \mathrm{~mL}$ with acetone $80 \%$. Tubes were centrifuged to separate the solid phases from the liquid phases by removing an aliquot of the liquid 
phase for absorbance reading in a spectrophotometer (Genesys 10S Spectrophotometer, UV-VIS®). Readings were carried out in the $663 \mathrm{~nm}$ wavelengths for chlorophyll $a$ and $645 \mathrm{~nm}$ for chlorophyll $b$. Chlorophyll content was determined by equations proposed by Arnon (1949) and results expressed in milligrams of chlorophyll per gram of fresh matter:

Chlorophyll $a\left(\mathrm{mg} \mathrm{g}^{-1}\right)=\left(12.7 \mathrm{~A}_{663}-2.69 \mathrm{~A}_{645}\right) 10 /$ (1000*samples mass)

Chlorophyll $b\left(\mathrm{mg} \mathrm{g}^{-1}\right)=\left(22.9 \mathrm{~A}_{645}-4.68 \mathrm{~A}_{663}\right) 10 /$ (1000*samples mass)

Chlorophyll $a+b\left(\mathrm{mg} \mathrm{g}^{-1}\right)=$ chlorophyll $a+$ chlorophyll $b$

Chlorophyll $a / b$ relationship: chlorophyll $a$ / chlorophyll $b$

Plants survival percentage was also evaluated during the acclimatization stage. Plants were transferred to styrofoam trays with 128 cells using sphagnum as substrate; each cell received a seedling and the set of seven plants consisted of one replication, a total of four replications per treatment
(28 plants). Trays were kept in a greenhouse with $70 \%$ of shading under daily dripping irrigations. Sixty days later, their survival percentage was verified.

Data statistical analysis was composed of individual analysis of variances and a combined analysis of the environments (type of lamp). Means were compared by the Tukey test at 5\% of probability.

\section{Results and Discussion}

Figure 1 shows the Power Spectral Density (PSD) for the studied light sources. LED strips show a bell-shaped PSD centered in their respective color wavelength (approximately $460 \mathrm{~nm}$ for the blue LED and $640 \mathrm{~nm}$ for the red LED). Phillips LEDtube lamps are similar to these strips but displaced. LEDtube 6500k shows its maximum in a smaller wavelength than LEDtube 4000k. Therefore, although being white LEDs, LEDtube 6500k tends towards the blue and LEDtube 4000k tends towards the red.

Figure 1. Energy spectral distribution related to LEDs and the fluorescent lamp.

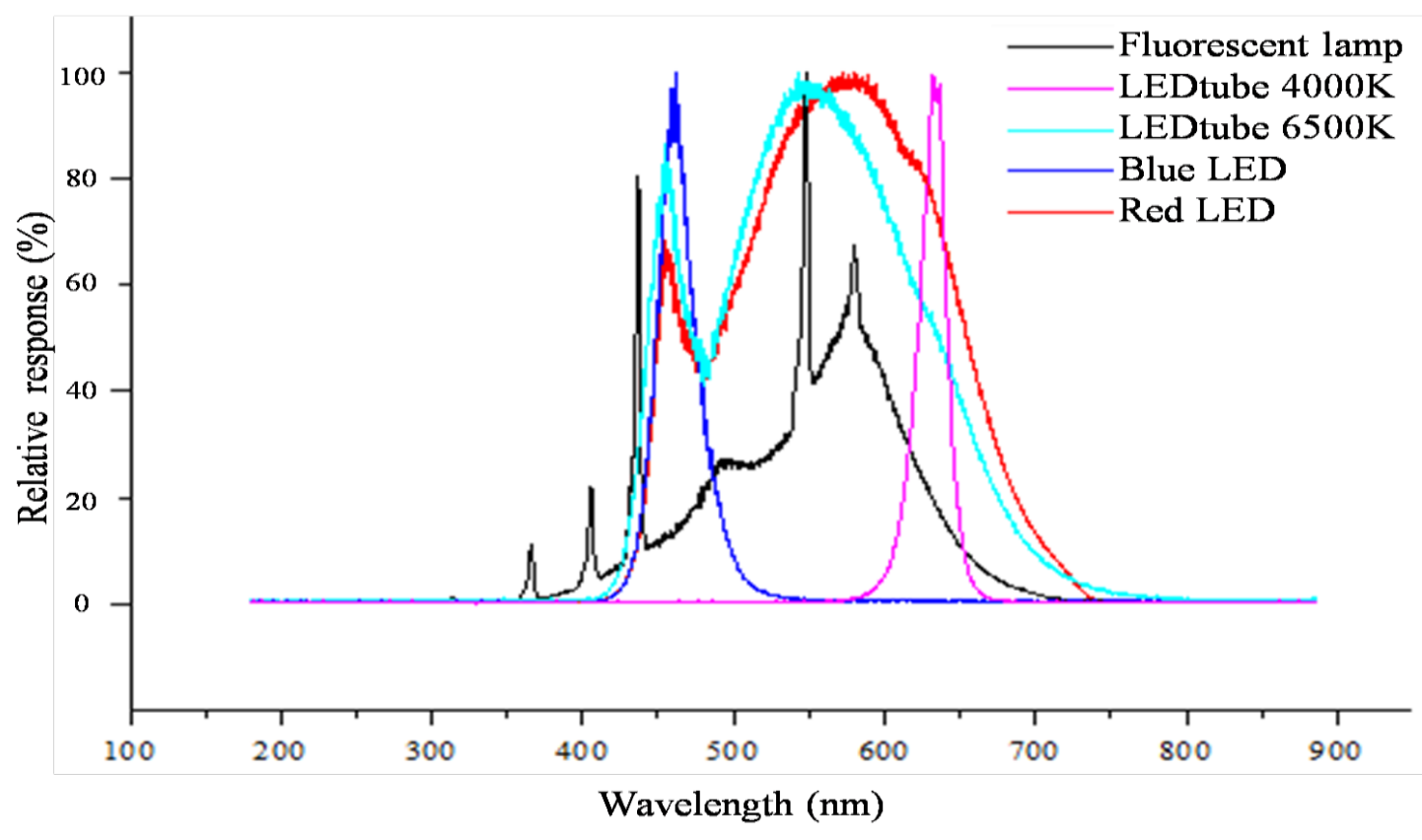


On the other hand, the fluorescent light showed intensity peaks in discrete wavelengths. This was attributed to the fact that the visible light (lower energy) is generated by a phosphorous layer excitation after the circulation of the electric current in the gas. Thus the phosphorous atom electron rises to discrete and well-defined energetic levels which when back to their normal state emit photons with defined energy and, consequently, specific wavelengths.

Light quality is one of the most important factors in plant development regulation, since there are phootoreceptors that are active under specific light wavelengths (LEE et al., 2007). In this study, Microlaelia lundii plants growth differences were verified when plants were submitted to different light sources and culture media (Table 2). For the canopy height variable there was an interaction between light sources and cultivation media. As for the simplified culture medium, taller plants in relation to the MS medium, except for light sources L2 and L5 (L2 - LEDtube 6500K, L5 - LED red), in which the canopy height did not differ between the two culture media formulations. As the fertilizer used in the simplified medium shows practically the same macro and micro nutrients present in the MS medium (FAVETTA et al., 2014), the increase in plants height was probably due to the addition of the banana pulp, since the pulp of 'Nanica' banana is a source of potassium and vitamins $\mathrm{A}$ and $\mathrm{C}$, thiamine, riboflavin and niacin (ARDITTI, 2008), components that enrich the nutritious media and increase in vitro plants growth (FAVETTA et al., 2014).

Table 2. Canopy variables in Microlaelia lundii seedlings submitted to different light sources and culture media.

\begin{tabular}{|c|c|c|c|c|c|c|}
\hline \multirow{2}{*}{ Lamp $^{\mathrm{x}}$} & \multicolumn{3}{|c|}{ Canopy height $(\mathrm{cm})$} & \multicolumn{3}{|c|}{ Number of shoots } \\
\hline & MS & SM & Mean & MS & SM & Mean \\
\hline $\mathrm{L} 1$ & $4.6 \mathrm{abB}^{\mathrm{y}}$ & $5.36 \mathrm{bcA}$ & 4.98 & 2.67 & 2.83 & $2.75 \mathrm{ab}$ \\
\hline L2 & $4.41 \mathrm{abA}$ & $4.88 \mathrm{bcA}$ & 4.64 & 2.75 & 3.00 & $2.88 \mathrm{ab}$ \\
\hline L3 & $3.39 \mathrm{cB}$ & $4.56 \mathrm{cA}$ & 3.98 & 3.04 & 3.63 & $3.33 \mathrm{a}$ \\
\hline L4 & $3.68 \mathrm{bcB}$ & $5.61 \mathrm{bA}$ & 4.64 & 1.88 & 2.54 & $2.21 \mathrm{~b}$ \\
\hline L5 & $5.17 \mathrm{aA}$ & $5.60 \mathrm{bA}$ & 5.38 & 0.75 & 0.75 & $0.75 \mathrm{c}$ \\
\hline L6 & $5.36 \mathrm{aB}$ & $6.67 \mathrm{aA}$ & 6.01 & 0.75 & 1.21 & $0.98 \mathrm{c}$ \\
\hline L7 & $2.91 \mathrm{cB}$ & $5.62 \mathrm{bA}$ & 4.27 & 0.75 & 1.12 & $0.94 \mathrm{c}$ \\
\hline Mean & 4.22 & 5.47 & & $1.86 \mathrm{~A}$ & $2.09 \mathrm{~A}$ & \\
\hline CV (\%) & & & & \multicolumn{2}{|c|}{33.16} & \\
\hline \multirow{2}{*}{ Lamp } & \multicolumn{3}{|c|}{ Canopy fresh mass $(\mathrm{g})^{\mathrm{z}}$} & \multicolumn{3}{|c|}{ Canopy dry mass $(\mathrm{g})^{\mathrm{z}}$} \\
\hline & MS & SM & Mean & MS & SM & Mean \\
\hline $\mathrm{L} 1$ & $1.45 \mathrm{aA}$ & $1.15 \mathrm{abcA}$ & 1.30 & $0.15 \mathrm{aA}$ & $0.14 \mathrm{bA}$ & 0.15 \\
\hline $\mathrm{L} 2$ & $1.42 \mathrm{aA}$ & $1.40 \mathrm{abA}$ & 1.41 & $0.17 \mathrm{aA}$ & $0.14 \mathrm{bA}$ & 0.15 \\
\hline L3 & $1.01 \mathrm{abcB}$ & $1.42 \mathrm{abA}$ & 1.21 & $0.14 \mathrm{aB}$ & $0.21 \mathrm{aA}$ & 0.17 \\
\hline L4 & $1.27 \mathrm{abA}$ & $1.50 \mathrm{aA}$ & 1.38 & $0.18 \mathrm{aB}$ & $0.22 \mathrm{aA}$ & 0.20 \\
\hline L5 & $0.80 \mathrm{bcA}$ & $0.74 \mathrm{cA}$ & 0.77 & $0.05 \mathrm{bA}$ & $0.05 \mathrm{cA}$ & 0.05 \\
\hline L6 & $1.13 \mathrm{abcA}$ & $0.93 \mathrm{bcA}$ & 1.03 & $0.07 \mathrm{bA}$ & $0.06 \mathrm{cA}$ & 0.07 \\
\hline L7 & $0.65 \mathrm{cA}$ & $0.85 \mathrm{cA}$ & 0.74 & $0.08 \mathrm{bB}$ & $0.13 \mathrm{bA}$ & 0.10 \\
\hline Mean & 1,10 & 1,14 & & 0.12 & 0.14 & \\
\hline CV (\%) & \multicolumn{3}{|c|}{20.81} & \multicolumn{2}{|c|}{17.20} & \\
\hline
\end{tabular}

x L1 - LEDtube 4000K; L2 - LEDtube 6500K; L3 - LEDtube 4000K + LEDtube 6500K; L4 - LEDtube 4000K + LEDtube 4000K; L5 - red LED ; L6 - blue LED; L7 - Flurescent lamp (control). MS - MS medium with half concentration of macronutrients and $\mathrm{SM}$ - simplified medium.

${ }^{y}$ Distinct lower case letters in the column and upper case letters in the line, for ech variable, differ by the Tukey test at $5 \%$ of significance. ${ }^{z}$ Values calculated based on the sum of seven plants. 
In studies with simplifed media, Unemoto et al. (2007) observed that Microlaelia lundii plants did not survive in the NPK fertilizer-based simplified medium (10-30-20), suggesting that they need a medium with greater complexity of elements. Therefore, this work shows that the presence of the 'Nanica' banana in the simplified culture medium supplied the plants need for nutrients, better than the MS medium.

In regards to light sources, L6 (blue LED) showed the highest mean for plants canopy height for the two analyzed culture media. However,
Poudel et al. (2008) and Heo et al. (2006) observed greater canopy height for grape plants grown under a red LED. Thus, in this work, this finding may indicate only an etiolation of plants due to lower luminosity, since the luminosity (lux) shown by the LEDs strips is, approximately, 15 times lower than the other light sources. Similar results were observed for seedlings that grew under light source L5. In addtion, seedlings submitted to light sources L5 and L6, for both culture media, showed a smaller number of shoots and less developed root system (Tables 2 and 3 ).

Table 3. Roots system variables evaluation of Microlaelia lundii seedlings submitted to different light sources and culture media.

\begin{tabular}{|c|c|c|c|c|c|c|}
\hline \multirow{2}{*}{ Lamp $^{\mathrm{x}}$} & \multicolumn{3}{|c|}{ Number of roots } & \multicolumn{3}{|c|}{ Roots average length $(\mathrm{cm})$} \\
\hline & MS & SM & Mean & MS & SM & Mean \\
\hline L1 & 8.38 & 9.54 & $8.96 \mathrm{a}^{\mathrm{y}}$ & $3.59 \mathrm{bA}$ & $4.05 \mathrm{bA}$ & 3.82 \\
\hline L2 & 8.58 & 9.38 & $8.98 \mathrm{a}$ & $3.07 \mathrm{bA}$ & $3.92 \mathrm{bA}$ & 3.50 \\
\hline L3 & 8.79 & 12.08 & $10.44 \mathrm{a}$ & $2.90 \mathrm{bA}$ & $3.47 \mathrm{bA}$ & 3.18 \\
\hline L4 & 7.21 & 10.21 & $8.71 \mathrm{a}$ & $3.39 \mathrm{bB}$ & $6.20 \mathrm{aA}$ & 4.8 \\
\hline L5 & 3.58 & 3.71 & $3.65 \mathrm{c}$ & $2.94 \mathrm{bA}$ & $3.35 \mathrm{bA}$ & 3.15 \\
\hline L6 & 4.46 & 4.13 & $4.29 \mathrm{bc}$ & $3.27 \mathrm{bA}$ & $4.02 \mathrm{bA}$ & 3.65 \\
\hline L7 & 4.46 & 7.29 & $6.38 \mathrm{~b}$ & $5.45 \mathrm{aA}$ & $5.54 \mathrm{aA}$ & 5.50 \\
\hline Mean & $6.64 \mathrm{~B}$ & $8.05 \mathrm{~A}$ & & 3.52 & 4.37 & \\
\hline CV (\%) & \multicolumn{3}{|c|}{20.45} & \multicolumn{2}{|c|}{15.90} & \\
\hline \multirow{2}{*}{ Lamp } & \multicolumn{3}{|c|}{ Roots fresh mass $(\mathrm{g})^{\mathrm{z}}$} & \multicolumn{3}{|c|}{ Roots dry mass $(\mathrm{g})^{\mathrm{z}}$} \\
\hline & MS & SM & Mean & MS & SM & Mean \\
\hline L1 & $1.88 \mathrm{abB}$ & $2.64 \mathrm{bA}$ & 2.26 & $0.21 \mathrm{abcB}$ & $0.29 \mathrm{bcA}$ & 0.25 \\
\hline L2 & $1.24 \mathrm{bB}$ & $2.14 \mathrm{bcA}$ & 1.69 & $0.15 \mathrm{cdeB}$ & $0.25 \mathrm{cA}$ & 0.20 \\
\hline L3 & $1.24 \mathrm{bB}$ & $2.19 \mathrm{bcA}$ & 1.71 & $0.18 \mathrm{bcdB}$ & $0.30 \mathrm{bcA}$ & 0.24 \\
\hline L4 & $1.65 \mathrm{abB}$ & $4.89 \mathrm{aA}$ & 3.27 & $0.26 \mathrm{abB}$ & $0.59 \mathrm{aA}$ & 0.42 \\
\hline L5 & $0.96 \mathrm{bA}$ & $1.04 \mathrm{dA}$ & 1.00 & $0.07 \mathrm{eA}$ & $0.08 \mathrm{dA}$ & 0.07 \\
\hline L6 & $1.09 \mathrm{bA}$ & $1.35 \mathrm{cdA}$ & 1.22 & $0.08 \mathrm{de} A$ & $0.11 \mathrm{dA}$ & 0.10 \\
\hline L7 & $2.49 \mathrm{aA}$ & $3.05 \mathrm{bA}$ & 2.77 & $0.29 \mathrm{aB}$ & $0.39 \mathrm{bA}$ & 0.34 \\
\hline Mean & 1.50 & 2.47 & & 0.18 & 0.29 & \\
\hline CV (\%) & \multicolumn{3}{|c|}{24.46} & \multicolumn{2}{|c|}{19.99} & \\
\hline
\end{tabular}

${ }^{x}$ L1 - LEDtube 4000K; L2 - LEDtube 6500K; L3 - LEDtube 4000K + LEDtube 6500K; L4 - LEDtube 4000K + LEDtube 4000K; L5 - red LED ; L6 - blue LED; L7 - Flurescent lamp (control). MS - MS medium with half concentration of macronutrients and $\mathrm{SM}$ - simplified medium.

${ }^{y}$ Distinct lower case letters in the column and upper case letters in the line, for ech variable, differ by the Tukey test at $5 \%$ of significance. ${ }^{z}$ Values calculated based on the sum of seven plants. 
For the shoots number variable (Table 2), there was no recorded significant effect of culture media, being the response to this variable influenced by the light source. Plants grown under light source L3, L2, L1 and L4 (L3 - LEDtube 4000k + LEDtube 6500k; L1 - LEDtube 4000k; L4 - LEDuube 4000k + LEDtube 4000k), respectively, showed greater number of shoots. However, the accumulation of dry mass in the canopy was due to the interaction between culture medium and light source. It is likely that number of shoots had a direct relationship with dry matter accumulation as verified for seedlings grown in the simplified culture medium under light sources L3 and L4.

This way, it can be inferred that the greater luminosity offered by these light sources and the greater supply of nutrients to the medium provided by the banana pulp stimulated synthesis and the accumulation of reserves by the shoots. Number of shoots is also important for the acclimatization stage since production maximization in shoot number, size and quality leads to greater survival percentage in this phase.

Culture medium composition and light source also influenced root system growth (Table 3). Thus, through an analysis of the variables related to the root system, it can be observed that roots induction is probably dependent on luminous intensity, corroborating with Lee et al. (2007).

LEDtubes L1, L2, L3 and L4, promoted greater number of roots per plant for the two culture media. However, longer roots were observed in plants grown under L7 (fluorescent lamps) in both media and under L4 in the simplified medium. For roots fresh and dry mass, superior values were observed for the simplified medium, under light source L4. In a study with simplified culture media with fruit pulps, for the in vitro growth of Cattleya bicolor, Souza et al. (2013) found no differences for roots and canopy dry mass when comparing the $1 / 2 \mathrm{MS}$ medium to the simplified medium composed by 'Nanica' banana pulp. This shows that the reaction to growth also depends on the interaction between species and culture medium.
In regards to chlorophyll content (Table 4), this study shows that there are differences between treatments and significant interactions between culture media and light sources. Greater chlorophyll $a$ and $b$ content was found in plants grown in the simplified medium for light sources L4 and L7. Rocha et al. (2010) and Nhut et al. (2003) observed greater chlorophyll content in strawberry shoots under red and red combined with blue LEDs, respectively. Light source L4 shows a tendency to red, corroborating with these authors' findings. On the other hand, Mengxi et al. (2011), in studies with Oncidium sp., obtained higher chlorophyll contents under blue LEDs.

Photsynthetic pigments showed greatrelevance to photosynthesis; they are related to cell multiplication and plants growth, being the chlorophyll responsible for absorption and for sending luminous energy to the reaction centers (TAIZ; ZEIGER, 2013). Thus, differences in radiation spectral quality may affect the composition of these pigments and, consequently, the whole photosynthetic functional apparatus (TOPCHIY et al., 2005). However, higher content of these pigments does not necessarily indicate higher photosyntetic percentage. Saebo et al. (1995), studying the arboreum species Betula pendula, found evidences that plants with lower chlorophyll content can use them more efficiently than seedlings with excessive chlorophyll.

The $a / b$ chlorophyll relationship (Table 4) showed significant interaction between factors, being the simplified medium superior to the $1 / 2 \mathrm{MS}$. Light source L4 showed greater relationship in the simplified medium, differeing however, only from L2 and L3. For the medicinal plant Withania somnifera, the higher percentage between clorophyl $a$ and $b$ was obtained by leaves that grew under a mix of red light and distant red (LEE et al., 2007).

During the acclimatization phase, the simplified culture medium showed a survival percentage higher than $90 \%$ (Table 5), indicating the superiority of this medium in relation to the $1 / 2$ MS for the cultivation of $M$. lundii. Considering the higher survival percentage, the light sources 
had no influence on the survival of these plants in during the acclimatization, especially under sources the simplified culture medium. However, the $1 / 2$

MS medium promoted lower survival percentages

Table 4. Content of $a$ chlorophyll, $b$ chlorophyll, $a+b$ chlorophyll and $a / b$ chlorophyll relationship in Microlaelia lundii seedlings submitted to different lamps and culture media.

\begin{tabular}{|c|c|c|c|c|c|c|}
\hline \multirow{2}{*}{ Lamp $^{x}$} & \multicolumn{3}{|c|}{ Chlorophyll $a\left(\mathrm{mg} \mathrm{g}^{-1}\right)$} & \multicolumn{3}{|c|}{ Chlorophyll $b\left(\mathrm{mg} \mathrm{g}^{-1}\right)$} \\
\hline & MS & SM & Mean & MS & SM & Mean \\
\hline L1 & $0.66 \mathrm{abA}^{\mathrm{y}}$ & $0.55 \mathrm{bA}$ & 0.61 & $0.40 \mathrm{abA}$ & $0.29 \mathrm{cB}$ & 0.35 \\
\hline L2 & $0.72 \mathrm{aA}$ & $0.57 \mathrm{bB}$ & 0.64 & $0.44 \mathrm{aA}$ & $0.32 \mathrm{bcB}$ & 0.38 \\
\hline L3 & $0.56 \mathrm{abA}$ & $0.51 \mathrm{bA}$ & 0.54 & $0.37 \mathrm{abA}$ & $0.28 \mathrm{cB}$ & 0.33 \\
\hline L4 & $0.64 \mathrm{abB}$ & $0.82 \mathrm{aA}$ & 0.73 & $0.38 \mathrm{abA}$ & $0.40 \mathrm{abA}$ & 0.39 \\
\hline L5 & $0.53 \mathrm{abA}$ & $0.54 \mathrm{bA}$ & 0.54 & $0.32 \mathrm{bA}$ & $0.29 \mathrm{cA}$ & 0.30 \\
\hline L6 & $0.52 \mathrm{bA}$ & $0.59 \mathrm{bA}$ & 0.56 & $0.34 \mathrm{bA}$ & $0.30 \mathrm{cA}$ & 0.32 \\
\hline L7 & $0.49 \mathrm{bB}$ & $0.89 \mathrm{aA}$ & 0.69 & $0.35 \mathrm{abB}$ & $0.46 \mathrm{aA}$ & 0.40 \\
\hline Mean & 0.59 & 0.64 & & 0.37 & 0.33 & \\
\hline $\mathrm{CV}(\%)$ & & & & \multicolumn{2}{|c|}{13.11} & \\
\hline \multirow{2}{*}{ Lamp } & \multicolumn{3}{|c|}{ Total Chlorophyll $a+b\left(\mathrm{mg} \mathrm{g}^{-1}\right)$} & \multicolumn{3}{|c|}{ Chlorophyll $a / b$ relationship $\left(\mathrm{mg} \mathrm{g}^{-1}\right)$} \\
\hline & MS & SM & Mean & MS & SM & Mean \\
\hline L1 & $1.06 \mathrm{abA}$ & $0.84 \mathrm{bB}$ & 0.95 & $1.66 \mathrm{abB}$ & $1.89 \mathrm{abcA}$ & 1.78 \\
\hline L2 & $1.16 \mathrm{aA}$ & $0.88 \mathrm{bB}$ & 1.02 & $1.63 \mathrm{abB}$ & $1.80 \mathrm{cA}$ & 1.72 \\
\hline L3 & $0.94 \mathrm{abA}$ & $0.79 \mathrm{bA}$ & 0.86 & $1.50 \mathrm{bcB}$ & $1.83 \mathrm{bcA}$ & 1.66 \\
\hline L4 & $1.02 \mathrm{abB}$ & $1.22 \mathrm{aA}$ & 1.12 & $1.71 \mathrm{aB}$ & $2.07 \mathrm{aA}$ & 1.89 \\
\hline L5 & $0.85 \mathrm{bA}$ & $0.83 \mathrm{bA}$ & 0.84 & $1.67 \mathrm{abB}$ & $1.90 \mathrm{abcA}$ & 1.79 \\
\hline L6 & $0.86 \mathrm{bA}$ & $0.89 \mathrm{bA}$ & 0.87 & $1.54 \mathrm{abcB}$ & $2,01 \mathrm{abA}$ & 1.77 \\
\hline L7 & $0.84 \mathrm{bB}$ & $1.34 \mathrm{aA}$ & 1.09 & $1.43 \mathrm{cB}$ & $1.92 \mathrm{abcA}$ & 1.68 \\
\hline Média & 0.96 & 0.97 & & 1.59 & 1.92 & \\
\hline CV (\%) & \multicolumn{3}{|c|}{13.70} & \multicolumn{2}{|c|}{5.18} & \\
\hline
\end{tabular}

${ }^{x}$ L1 - LEDtube 4000K; L2 - LEDtube 6500K; L3 - LEDtube 4000K + LEDtube 6500K; L4 - LEDtube 4000K + LEDtube 4000K; L5 - red LED ; L6 - blue LED; L7 - Flurescent lamp (control). MS - MS medium with half concentration of macronutrients and $\mathrm{SM}$ - simplified medium.

y Distinct lower case letters in the column and upper case letters in the line, for ech variable, differ by the Tukey test at $5 \%$ of significance.

Table 5. Survival percentage of Microlaelia lundii plants submitted to different lamps and culture media acclimatizated in esphagnum as substrate.

\begin{tabular}{ccc}
\hline Lamp $^{\mathrm{x}}$ & \multicolumn{3}{c}{ Survival (\%) } \\
\cline { 2 - 3 } & MS & SM \\
\hline L1 & $75.00 \mathrm{aB}^{\mathrm{y}}$ & $100.00 \mathrm{aA}$ \\
L2 & $64.29 \mathrm{abB}$ & $92.86 \mathrm{aA}$ \\
L3 & $53.57 \mathrm{abB}$ & $100.00 \mathrm{aA}$ \\
L4 & $18.45 \mathrm{cB}$ & $100.00 \mathrm{aA}$ \\
L5 & $35.71 \mathrm{abcB}$ & $96.43 \mathrm{aA}$ \\
L6 & $35.71 \mathrm{abcB}$ & $96.43 \mathrm{aA}$ \\
L7 & $25.00 \mathrm{bcB}$ & $96.43 \mathrm{aA}$ \\
\hline CV (\%) & &
\end{tabular}

${ }^{\mathrm{x}}$ L1 - LEDtube 4000K; L2 - LEDtube 6500K; L3 - LEDtube 4000K + LEDtube 6500K; L4 - LEDtube 4000K + LEDtube 4000K; L5 - red LED ; L6 - blue LED; L7 - Flurescent lamp (control). MS - MS medium with half concentration of macronutrients and $\mathrm{SM}$ - simplified medium.

${ }^{\mathrm{y}}$ Distinct lower case letters in the column and upper case letters in the line, for ech variable, differ by the Tukey test at $5 \%$ of significance. 
In summary, the simplified culture medium in the light sources L1, L2, L3 and L4 offered better conditions for plant develelopment, ensuring great survival percentage during the aclimatization phase. Although the fluorescent lamp presented similar results to the LEDs for several variables, the use of LEDs is recommended for economic and environment preservation purposes. Moreover, as light sources L1, L2 and L3, L4 showed similar results, the use of sources L1 and L2 reduces installation and maintenance costs, since these treatments use only one lamp and not two as treatments L3 and L4.

\section{Conclusion}

The simplified culture medium composed of Biofert ${ }^{\circledR}$ and 'Nanica' banana pulp in light sources L1, L2, L3 and L4 are recommended for the in vitro propagation of Microlaelia lundii.

\section{References}

ARAÚJO, A. G.; PASQUAL, M.; VILLA, F.; COSTA, F. C. Água de coco e polpa de banana no cultivo in vitro de plântulas de orquídea. Revista Ceres, Viçosa, MG, v. 53, n. 310, p. 608-613, 2006.

ARDITTI, J. Microporpagation od archids. California: Wiley, 2008. $1560 \mathrm{p}$.

ARNON, D. I. Copper enzymes in isolated chloroplasts: polyphenoloxidases in Beta vulgais. Plant Physiology, Rockville, v. 24, n. 1, p. 1-15, 1949.

BAQUE, M. A.; SHIN, Y. K.; ELSHMARI, T.; LEE, J.; PAEK, K. Y. Effect of light quality, sucrose and coconut water concentration on the microporpagation of Calanthe hybrids (Bukduseong $\times$ Hyesung and Chunkwang $\times$ Hyesung). Australian Journal of Crop Science, Sydney, v. 5, n. 1, p. 1247-1254, 2011.

COLOMBO, R. C.; FAVETTA, V.; FARIA, R. T. Fertilizantes comerciais e polpa de banana no cultivo in vitro de um híbrido de Phalaenopsis (Orchidaceae). Revista Ceres, Viçosa, MG, v. 59, n. 6, p. 873-876, 2012.

FARIA, R. T.; SANTIAGO, D. C.; SARIDAKIS, D. P.; ALBINO, U. B.; ARAÚJO, R. Preservation of the brazilian orchid Cattleya walkeriana Gardner using in vitro propagation. Crop Breeding and Applied Biotechnology, Viçosa, MG, v. 2, n. 3, p. 489-492, 2002.

FAVETTA, V.; COLOMBO, R. C.; FARIA, R. T. Cultivo in vitro de Vanda tricolor Lindl. em meios de cultura simplificados. Revista Ciencias Agrárias, Belém, v. 57, n. 2, p. 114-117, 2014.

GUPTA, S. D.; JATOTHU, B. Fundamentals and applications of light-emitting diodes (LEDs) in vitro plant growth and morphogenesis. Plant Biotechnology Reports, Heidelberg, v. 7, n. 3, p. 211-220, 2013.

HEO, J. W.; SHIN, K. S.; KIM, S. K.; PAEK, K. Y. Light quality affects in vitro growth of grape Teleki 5BB. Journal of Plant Biology, New York, v. 49, n. 4, p. 276280, 2006.

KERBAUY, G. B.; CHAER, L. Micropropagação comercial de orquídeas: conquistas, desafios e perspectivas. In: LEE, T. S. G. Biofábrica de plantas: produção industrial de plantas in vitro. São Paulo: Antiqua, 2011. p. 178-205.

LEE, S. H.; TEWARI, R. K.; HAHN, E. J.; PAEK, K. Y. Photon flux density and light quality induce changes in growth, stomatal development, photosynthesis and transpiration of Withania somnifera (L.) Dunal. plantlets. Plant Cell, Tissue and Organ Culture, Amsterdam, v. 90, n. 2, p. 141-151, 2007.

MENGXI, L.; ZHIGANG, X.; YANG, Y.; FENG, Y. Effects of different spectral lights on Oncidium PLBs induction, proliferation, and plant regeneration. Plant Cell, Tissue and Organ Culture, Amsterdam, v. 106, n. 1, p. 1-10, 2011.

MIYATA, L. Y.; VILLA, F.; PASQUAL, M. Meios de cultura utilizados na micropropagação de híbridos de orquídeas. Semina: Ciências Agrárias, Londrina, v. 35, n. 4, p. 1731-1738, 2014.

MORAES, L.; FARIA, R. T.; CUQUEL, F. L. Activated charcoal for in vitro propagation of brazilian orchids. Acta Horticulturae, Wageningen, v. 683, n. 1, p. 383-390, 2005.

MURASHIGE, T.; SKOOG, F. A revised medium for rapid growth and biossays with tobacco tissue culture. Physiologia Plantarum, Copenhagen, v. 15, n. 3, p. 473497, 1962.

NHUT, D. T.; TAKAMURA, T.; WATANABE, H.; OKAMOTO, K.; TANAKA, M. Responses of strawberry plantlets cultured in vitro under superbright red and blue light-emitting diodes (LEDs). Plant Cell, Tissue and Organ Culture, Amsterdam, v. 73, n. 1, p. 43-52, 2003. 
NHUT, D. T.; TAKAMURA, T.; WATANABE, H.; TANAKA, M. Artificial light source using light-emitting diodes (LEDs) in the efficient micropropagation of Spathiphyllum plantlets. Acta Horticulture, Wageningen, v. 692, n. 1, p. 137-142, 2005.

POUDEL, P. R.; KATAOKA, I.; MOCHIOKA R. Effect of red- and blue-light-emitting diodes on growth and morphogenesis of grapes. Plant Cell, Tissue and Organ Culture, Amsterdam, v. 92, n. 2, p. 147-153, 2008.

ROCHA, P. S. G.; OLIVEIRA, R. P.; SCIVITTARO, W. B.; SANTOS, U. L. Diodos emissores de luz e concentrações de BAP na multiplicação in vitro de morangueiro. Ciência Rural, Santa Maria, v. 40, n. 9, p. 1922-1928, 2010.

SAEBO, A.; KREKLING, T.; APPELGREN, M. Light quality affects photosynthesis and leaf anatomy of birch plantlets in vitro. Plant Cell, Tissue and Organ Culture, Amsterdam, v. 41, n. 1, p. 177-185, 1995.

SOUZA, G. R. B.; LONE, A. B.; FARIA, R. T.; OLIVEIRA, K. S. Pulp fruit added to culture medium for in vitro orchid development. Semina: Ciências Agrárias, Londrina, v. 34, n. 3, p. 1141-1146, 2013.

STANCATO, G. C.; ABREU, M. F.; FURLANI, A. M. C. Crescimento de orquídeas epífitas in vitro: adição de polpa de frutos. Bragantia, Campinas, v. 67, n. 1, p. 5157, 2008.
STANCATO, G. C.; NÉRI, F. C. S.; TAVARES, A. R. Micropropagação de violeta africana. Revista Brasileira de Horticultura Ornamental, Campinas, v. 15, n. 2, p. 165-170, 2009.

SU, M. J.; SCHNITZER, J. A.; FARIA, R. T. Polpa de banana e fertilizantes comerciais no cultivo in vitro de orquídea. Cientifica: Revista de Ciências Agrárias, Jaboticabal, v. 40, n. 1, p. 28-34, 2012.

TAIZ, L.; ZEIGER, E. Fisiologia vegetal. 5. ed. Porto Alegre: ArtMed, 2013. 954 p.

TOPCHIY, N. M.; SYTNIK, S. K.; SYVASH, O. O.; ZOLOTAREVA, O. K. The effect of additional red irradiation on the photosynthetic apparatus of Pisum sativum. Photosynthetica, Heidelberg, v. 43, n. 3, p. 451456, 2005.

UNEMOTO, L. K.; FARIA, R. T. de; VIEIRA, A. O. S.; DALIO, R. J. D. Propagação in vitro de orquídeas brasileiras em meio de cultura simplificado. Revista Brasileira de Agrociência, Pelotas, v. 13, n. 2, p. 267269, 2007.

VALENTIM, A. B.; FERREIRA, H. S.; COLETTO, M. A. Lâmpadas de LED: impacto no consumo e fator de potência. Ciências do Ambiente, v. 6, n. 1, p. 29-36, 2010. 